\title{
Financial Performance before and during the Covid-19 Pandemic on Islamic Microfinance Institutions (Case Study Btm Kaliwungu)
}

\author{
Nur Khatik*, Fatmasari Sukesti, Ida Kristiana \\ Department of Accounting, Faculty of Economics, Universitas Muhammadiyah Semarang, Indonesia
}

Received August 30, 2021; Revised January 15, 2022; Accepted February 8, 2022

\section{Cite This Paper in the following Citation Styles}

(a): [1] Nur Khatik, Fatmasari Sukesti, Ida Kristiana, "Financial Performance before and during the Covid-19 Pandemic on Islamic Microfinance Institutions (Case Study Btm Kaliwungu)," Universal Journal of Accounting and Finance, Vol. 10, No. 2, pp. 559 - 565, 2022. DOI: 10.13189/ujaf.2022.100220.

(b): Nur Khatik, Fatmasari Sukesti, Ida Kristiana (2022). Financial Performance before and during the Covid-19 Pandemic on Islamic Microfinance Institutions (Case Study Btm Kaliwungu). Universal Journal of Accounting and Finance, 10(2), 559 - 565. DOI: 10.13189/ujaf.2022.100220.

Copyright $\mathrm{C} 2022$ by authors, all rights reserved. Authors agree that this article remains permanently open access under the terms of the Creative Commons Attribution License 4.0 International License

\begin{abstract}
Islamic banking in Indonesia is facing a number of challenges in the midst of the Covid-19 pandemic, and impacting Sharia Micro Finance Institutions will face several potential risks to financial performance. For this reason, research is needed to analyze the impact of Covid-19 on sharia microfinance performance. In this case, BTM Kaliwungu analyzes financial statements using financial ratios, namely Return On Asset (ROA), Capital Adequacy Ratio (CAR), Non-Performing Finance (NPF) and Financing Deposit to Ratio (FDR). This is a quantitative study with trend analysis in Microsoft Excel. The data were collected three years (December 31, 2017December 31, 2019) before and one year (December 31, 2020) after the announcement of the first case of Covid-19 on March 2, 2020. The financial statements demonstrate the overall impact of Covid-19 on sharia microfinance performance (BTM Kaliwungu). During the existence of covid-19, the CAR ratio has no effect. ROA displays the results of criterion calculation quite well before or during the Covid-19 pandemic. The NPF calculation results show that the poor standard is still within the acceptable standardized range. Furthermore, in the case of FDR, it necessitates a greater reliance on third-party funding.
\end{abstract}

Keywords Financial Performance, CAR, ROA, NPF, FDR

\section{Introduction}

During the Covid-19 pandemic, the Indonesian government paid attention to three sectors: health, the real sector, and banking [1]. The Covid pandemic is a problem for financial institutions, including sharia microfinance institutions, because it can cause problems in the real sector or business world thatcould lead to problems in the banking sector. This issue is likely to arise because the banking sector serves as an intermediation institution or intermediary for the needs of investment funds in the business world.

The Central Statistics Agency (Badan Pusat Statistiks) reports that, in August 2020, Indonesia's economic growth in the second quarter was minus $5.32 \%$, which in the first quarter grew by $2.97 \%$, and significantly lower than the 5.02 percent growth in the same period of 2019 [2]. Indonesia's economy will fall by negative 2.9 percent to 1.1 percent in the third quarter, as predicted by Finance Minister Sri Mulyani Indrawati, indicating that the country will enter an economic recession [3].

The effect also left in Islamic microfinance institutions. BTM Kaliwungu is a sharia microfinance institution that incorporates cooperatives, sharia savings and loans, and sharia financing. It is an institution that provides financial services in the micro-region, which serves the lower middle class and improves the basic capabilities needed by the community to develop their business, such as resources, education, and social networks. 
The micro financing sector has proved to be beneficial for developing countries in terms of poverty alleviation, creating more opportunities and better standards of living [4].

In the current Covid-19 pandemic, Islamic microfinance institutions will face several possible risks, such as the risk of bad financing (NPF), market risk, and liquidity risk [5]. Therefore, these risks will eventually have an impact on the performance and profitability of the sharia micro institution [6].

As a result, research is needed to analyze the impact of Covid-19 on the financial performance of sharia banking by analyzing financial statements using financial ratios, namely Return on Asset (ROA), Capital Adequacy Ratio (CAR), Non Performing Finance (NPF) and Financing Deposit to Ratio (FDR).

\section{Literature Review}

\subsection{BTM (Baitul Tamwil Muhammadiyah)}

Baitul Tamwil is a combination of two concept, namely Bait (House) and Tamwil (development of wealth), which were originally said to be Maal or treasure. Understanding the two syllables is then used as an investment for microfinance institutions, namely serving as a business development institution [7].

BTM is a financial institution that operates on sharia principles. Sharia principles mean that all financial transactions are carried out with an agreement in accordance with Islamic sharia. The position of this financial institution is the Muhammadiyah Economic Business Charity. In principle, the position of BTM is the same as other Muhammadiyah Charity, for example, schools, hospitals, and orphanages. However, because this is a business institution, management has full authority in the management of BTM. [7]

\subsection{Financial Performance}

Company performance can be assessed through various indicators or variables to measure the company's success, generally focusing on performance information derived from financial reports [8]. Financial performance is something that a company produces or obtains as a result of its efforts. The extent to which the company has implemented by using financial implementation rules correctly and adequately [9]. Such as by making a financial statement that has been in accordance with the provisions in SAK (Standards of Financial Accounting) or GAAP (General Acepted Accounting Principle).

Financial performance is the condition of the company's financial statements at a certain period, both in terms of raising and distributing funds. The proxy used to measure financial performance by using financial ratios Capital Adequacy Ratio (CAR), Return on Assets (ROA),
Non-Performing Financing (NPF), and Financing to Deposit Ratio (FDR).

Based on the above, financial performance is a condition of the company's financial picture, which is a microfinance institution in a particular period, whether it is the collection or distribution of funds.

\subsection{Financial Ratio}

According to Fahmi [10], numbers in the financial statements are calculated by dividing one number by another number. Comparisons can be made between one component and components in the same financial report, as well as between components in different financial statements. Conducting financial ratio analysis can be carried out in two ways of comparison [11], namely:

1. Compare the present ratio with the ratios of the past time (ratio history) or with the ratios estimated for the coming times of the same company. By this comparison, we will be able to know the changes in that ratio from year to year if it is known that the difference in the number of ratios can be concluded about the tendency or tendency of the financial situation and the results of the operations of the company concerned.

2. It compares the ratios of a company to such ratios of other similar or industrial companies (industry ratios/ standard ratios) for the same time. In this manner, it will be determined whether the company concerned is above, at, or below the industry average in certain financial aspects.

\subsubsection{Capital Adequacy Ratio (CAR)}

Capital adequacy ratio (CAR) is a ratio related to bank capital that measures the capital factor owned by banks to develop risky assets. When the capital owned by the bank is expected to be able to take advantage of the risks that cannot be avoided, then the bank can manage it properly, so that the wealth owned by the bank increases and vice versa (Pramudhito, 2014) [12].

CAR is an indicator of a bank's ability to cover its declining assets due to bank losses caused by risky assets with the adequacy of its capital [13]. The higher the CAR, The higher the CAR, the more capable the bank is of bearing the risk of any risky productive loans or assets. In other words, the higher the adequacy of its capital to bear the risk of bad loans, the better the bank's performance will be, and can increase public confidence in the bank concerned, which leads to increased profits (ROA) (Ruslim, 2012). The CAR (Capital Adequacy Ratio) calculation is formulated as follows:

$$
\mathrm{CAR}=\frac{\text { TOTAL CAPITAL } x 100 \%}{\text { RISK }- \text { WEIGHTED ASSETS }}
$$

\subsubsection{Return on Assets (ROA)}

Return on assets is an indicator of how reliable the company is in exploiting assets to generate profits. ROA is 
usually calculated by dividing net income by the company's assets as a whole [14].

Return on assets (ROA) is used to measure the company's ability to generate net income based on certain asset levels. This ratio shows the ability of economic resources invested in overall assets to earn a net profit. In other words, how much profit is earned on each rupiah invested in assets [15].

Return on assets usually appears in the form of a percentage calculated by the ROA formula. The greater the percentage, the more productive and efficient a company is. And vice versa, the smaller the ROA percentage, the sign the company is less productive.

According to Dewi and Prasetyono [16], a company's effectiveness in making profits by utilizing its assets. Its function is to see how effective banking uses its assets to generate income. The greater the value of ROA means that the better the ability of banking in generating profits. The formula for calculating ROA is follows:

$$
\text { ROA }=\frac{\text { NET PROFIT BEFORE TAX } \times 100 \%}{\text { TOTAL ASSETS }}
$$

\subsubsection{Non-Performing Financing (NPF)}

The Non-Performing Finance (NPF) ratio is one of the indicators used to assess the ease with which customers fulfill their obligations. NPF is a ratio that shows the comparison between non-performing financing and the amount of financing disbursed by Islamic banks [17]

The higher the NPF level, the greater the financing risk that the bank will bear. Due to the high NPF, banks are required to provide larger reserves, which reduce the capital reserves owned by banks [18].

A high NPF will magnify costs, potentially against bank losses. The higher this ratio, the worse the quality of bank loans, resulting in a greater number of problem loans, and thus the bank must bear losses in its operations, decreasing the profit (ROA) obtained by the bank [10]. The formula for calculating NPF is as follows:

$$
\mathrm{NPF}=\frac{\text { FINANCING PROBLEM } \mathrm{x} 100 \%}{\text { TOTAL FINANCING }}
$$

\subsubsection{Financing to Deposit Ratio (FDR)}

Financing to Deposit Ratio (FDR) is a ratio used to measure the liquidity of a bank in paying back withdrawals made by depositors by relying on the financing provided as a source of liquidity, namely by dividing the amount of financing provided by the bank to Third Party Funds [19]. FDR is a tool to measure the extent to which the bank's ability to pay withdrawals from depositors whose funds have been directly distributed by the bank to the public by way of loans [20] and a measuring tool to measure the volume of financing so that this FDR ratio can show the health of the bank in providing financing [21].

FDR is a measure of liquidity that measures the number of funds placed in the form of loans derived from funds collected by banks (especially the public). Suppose the measurement results are far above the target and limit. In that case, the bank will likely to experience liquidity difficulties, which will cause pressure on bank income [22]. The higher the FDR, the company's profit increases (assuming the bank is able to distribute loans effectively so that the number of bad loans will be small). The formula for calculating FDR is as follows:

$$
\mathrm{FDR}=\frac{\text { FINANCING PROVIDED } \times 100 \%}{\text { THIRD }- \text { PARTY FUNDS }}
$$

\section{Research Methods}

This research is a case study, which is research conducted about certain objects in a company so that the conclusions made based on this analysis only apply limited to the company that is the company studied, namely BTM Kaliwungu. The data taken is three years (December 31, 2017-February 2019) before and one year (December 31, 2020) after the announcement of the first case of Covid-19 on March 2, 2020.

This test is used to measure how much difference BTM Kaliwungu's financial performance was before the announcement of the first Covid-19 case in Indonesia and after the announcement. Data processing in this study uses ratio analysis then with trend analysis (excel).

The variables used in this study are:

1. Data before Covid-19 cases are announced nationally in Indonesia for first times. Data before the national development of Covid-19 cases in Indonesia for the first time includes data on financial statements in the form of CAR (Capital Adequacy Ratio), ROA (Return on Assets), NPF (Non Performing Financing) and FDR (Financing to Deposit Ratio). In this study, data taken before the first case of coronavirus data financial statements for three years before the announcement of Covd-19 (financial statements as of December 31, 2017 to December 31, 2019).

2. Data after the national announcement of Covid-19 cases in Indonesia for the first time includes data on CAR (Capital Adequacy Ratio), ROA (Return on Assets), NPF (NonPerforming Financing) and FDR (Financing to Deposit Ratio). In this study, data was taken after the first case of covid-19 as one year (as of December 31, 2020).

\section{Results and Discussions}

\subsection{CAR Calculation}

Based on table 1, a percentage of 26.68 percent was seen in 2017, a percentage of 23.55 percent was seen in 2018, and a percentage of 19.15 percent was seen in 2019. During the COVID-19 pandemic, there was an increase of $20.77 \%$ compared to 2019. Based on Bank Indonesia regulations, the minimum CAR standard is $8 \%$. The CAR value in this 
sample period is still in good condition because it is still above the minimum Bank Indonesia requirement. Similarly, the Sharia Savings and Loans, Cooperatives, and Financing policies were evaluated. Judging from the ratio before Covid-19, it shows a healthy condition both before and during the Covid-19 period. It is still in good health.

Table 1. Calculation of CAR Ratio BTM Kaliwungu Before covid-19 (2017-2019) and during covid-19 (2020)

\begin{tabular}{|c|c|c|}
\hline YEAR & NOMINAL (Rp) & \% \\
\hline 2017 & $\frac{743,788,337.81}{2.787,915,806.94}$ & 26.68 \\
\hline 2018 & $\underline{854,904,980.44}$ & 23.55 \\
\hline 2019 & $\frac{9929,996,577.57}{5,195,722,331.14}$ & 19.15 \\
\hline 2020 & $\underline{1,102,232,982.84}$ & 20.77 \\
\hline
\end{tabular}

Likewise, trend analysis (figure 1) shows that before the Covid-19 pandemic, it showed a downward trend from 2017 (number 1) to 2019 (number 3), while during the Covid-19 pandemic, it showed an increasing graph in 2020 (number 4), meaning that Covid-19 pandemic has no effect on the capital in BTM Kaliwungu.

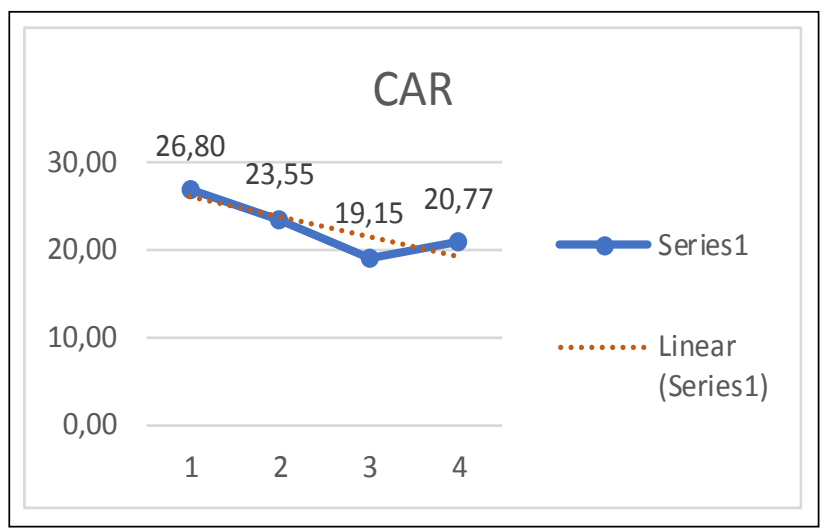

Figure 1. Trend analysis for CAR BTM Kaliwungu

\subsection{Calculation of ROA}

Based on (Regulation of the Minister of State for Cooperatives and Small and Medium Enterprises of the Republic of Indonesia Number 06/Per/M, 2006) ROA standards, the standard criteria are $\geq 10 \%$, the standard criteria for good are $7 \%-10 \%$, the standard criteria for good enough are $3 \%-7 \%$, the standard criteria for less good are $1 \%-3 \%$, and the standard criteria for not good are $<1 \%$.

The calculation of the ROA ratio can be seen in table 2, which shows that before the Covid-19 pandemic, it showed a percentage of $7.19 \%$ in 2017 , a percentage of $7.35 \%$ in 2018 , and a percentage of $5.70 \%$ in 2019 , while during the COVID-19 pandemic, namely in 2020, it showed a declining percentage of $4.57 \%$. As a result, the ROA from 2017 and 2018 is good, while the ROA in 2019 shows a fairly good decline in standards. Meanwhile, the results of the ROA calculation show that it decreased during the Covid-19 pandemic, but the criteria are still quite good.

Table 2. Calculation of ROA Ratio BTM Kaliwungu Before covid-19 (2017-2019) and during covid-19 (2020)

\begin{tabular}{|c|c|c|}
\hline YEAR & NOMINAL (Rp) & \% \\
\hline 2017 & $\underline{243,279,841.73}$ & 7.19 \\
\hline 2018 & $\frac{266,266,519,410.4}{3,620,666,712.13}$ & 7.35 \\
\hline 2019 & $\frac{270,071,963.16}{4,736,945,337.23}$ & 5.70 \\
\hline 2020 & $\underline{267,769,710.91}$ & 4.57 \\
\hline
\end{tabular}

Trend analysis for ROA can be seen in figure 2, which reveals that before the covid-19 pandemic, the graph decreased from 2019 (number 3), but during the Covid-19 pandemic, the graph declined from 2020 (number 4), indicating that there is an influence on ROA during the Covid-19 pandemic.

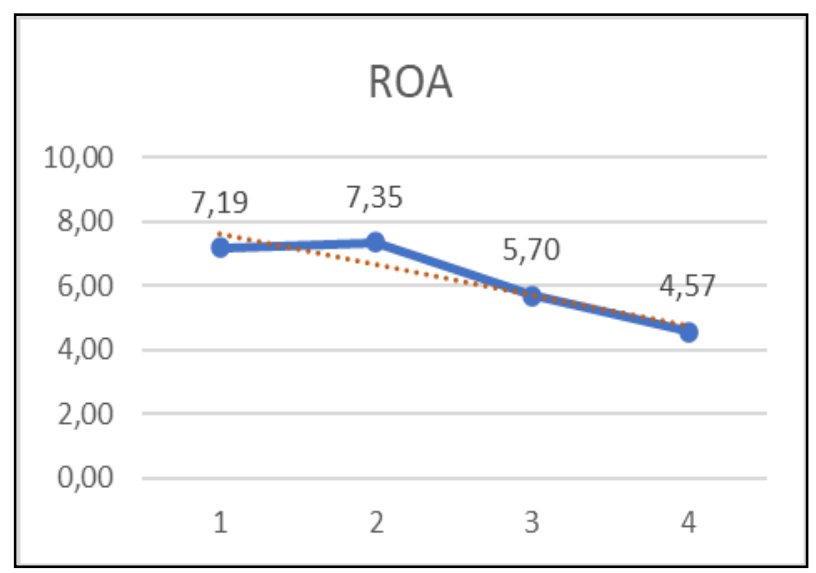

Figure 2. Trend analysis for ROA BTM Kaliwungu pandemic

\subsection{Calculation of NPF Ratio}

The smaller the value of NPF, the better the level of smooth payment of loans to the financial institution. As for the standard set by Bank Indonesia, the criteria are: very good $\mathrm{NPF}<2 \%$, both the standard is $2 \% \leq \mathrm{NPF} \leq 5 \%$, quite good the standard is $5 \% \leq \mathrm{NPF} \leq 8 \%$, not good standard $8 \%$ $\leq \mathrm{NPF} \leq 12 \%$. [24]

The calculation of the NPF ratio can be seen in table 3, which shows that before the Covid-19 pandemic, in 2017, it showed a percentage of $3.74 \%$ that could be declared good, for 2018, it showed a percentage of $7.19 \%$ that means quite good, for 2019, it showed a percentage of $9.47 \%$ that means it is not good, while during the Covid-19 pandemic, in 2020, the percentage of the number increased by $10.18 \%$, indicating that there was a delay in loan payments from customers to BTM Kaliwungu during the covid-19 pandemic, which was higher in compared to the years before the pandemic. 


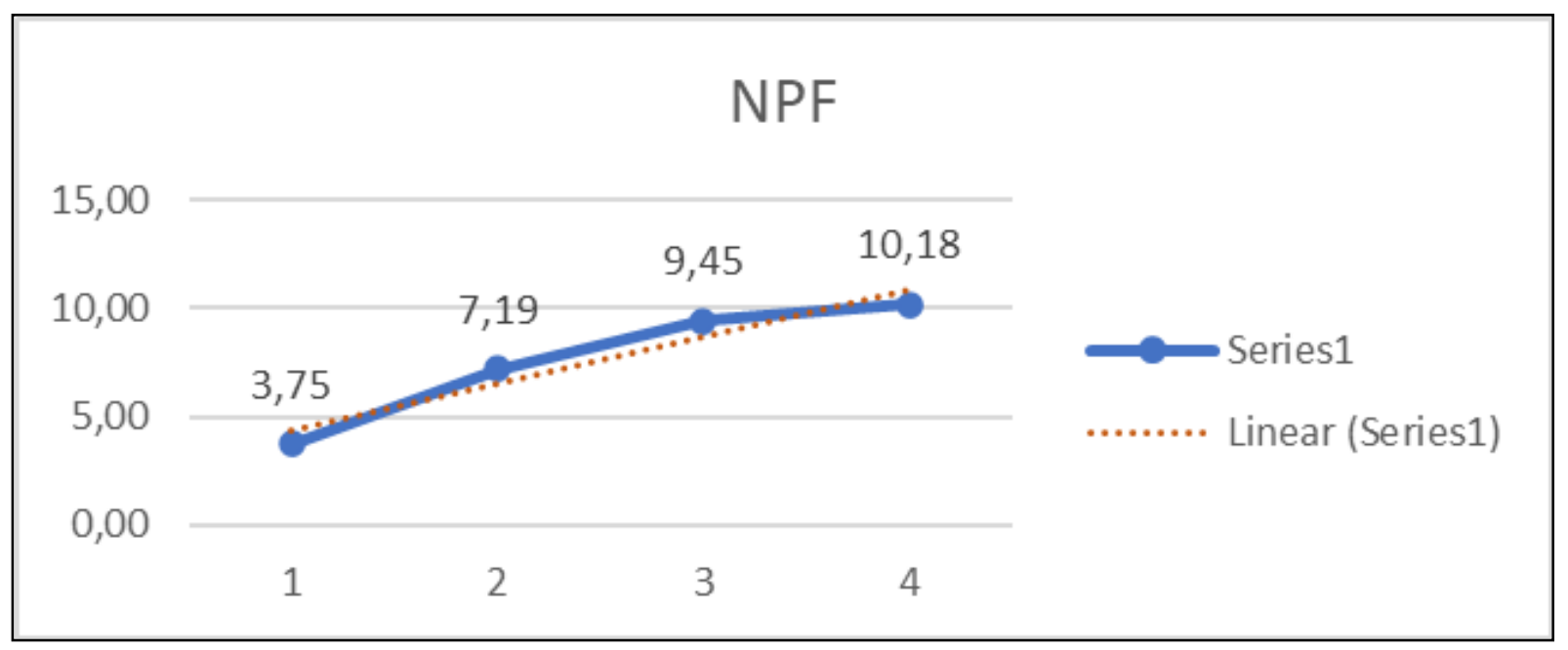

Figure 3. Trend analysis for NPF BTM Kaliwungu

Table 3. Calculation of NPF Ratio BTM Kaliwungu Before covid-19 (2017-2019) and during covid-19 (2020)

\begin{tabular}{|c|c|c|}
\hline YEAR & NOMINAL (Rp) & \% \\
\hline 2017 & $\frac{84,281,647.00}{2,251,213,953.00}$ & 3.74 \\
\hline 2018 & $\underline{234.073,425.00}$ & 7.19 \\
\hline 2019 & $\frac{3,256,640,473.00}{355,949,413.00}$ & 9.47 \\
\hline 2020 & $\underline{362,196,86,979.00}$ & 10.18 \\
\hline
\end{tabular}

Trend analysis for NPF can be seen in figure 3 showing that before the covid-19 pandemic in 2017 (number 1) it still showed a reasonable graph, the graph increased from 2018 (number 2), as well as in 2019 (number 3) also showed an increase. Meanwhile, during the Covid-19 pandemic, which shows an increasing graph in 2020 (number 4), it can be said that during the COVID-19 pandemic there was an increase in NPF during the covid-19 pandemic.

\subsection{Calculation of FDR Ratio}

The financing to deposit ratio (FDR) ratio of Islamic banking is considered adequate to support high yields if it is in the range of $95 \%-98 \%$. (Bisnis.com, 2014) While the Circular Letter of Bank Indonesia stipulates that the level of good liquidity is $78 \%-100 \%$.

The calculation of the FDR ratio can be seen in table 4, showing that before the Covid-19 pandemic, in 2017 it showed a percentage of $58.54 \%$ which could be declared in effective, for 2018 it showed a percentage of $81.27 \%$ which means that it shows a good level of liquidity, for 2019 it shows a percentage of $64.13 \%$ means that there is a decrease related to the use of third party funds, while during the covid-19 pandemic, in 2020, the percentage of the number decreased by $57.41 \%$. This means that during the covid-19 pandemic there was a decline lower than the previous year. This shows that BTM Kaliwungu does not utilize third party funds to the maximum.

Table 4. Calculation of FDR Ratio BTM Kaliwungu before covid-19 (2017-2019) and during covid-19 (2020)

\begin{tabular}{|c|c|c|}
\hline YEAR & NOMINAL (Rp) & \% \\
\hline 2017 & $\frac{2,251,213,953.00}{3,845,864,853.81}$ & 58.54 \\
\hline 2018 & $\frac{3.256 .640 .473,00}{4,007,286,946.44}$ & 81.27 \\
\hline 2019 & $\frac{3,758,919,879.00}{5,861,684,210.14}$ & 64.13 \\
\hline 2020 & $\underline{3,559,211,647.00}$ & 57.41 \\
\hline
\end{tabular}

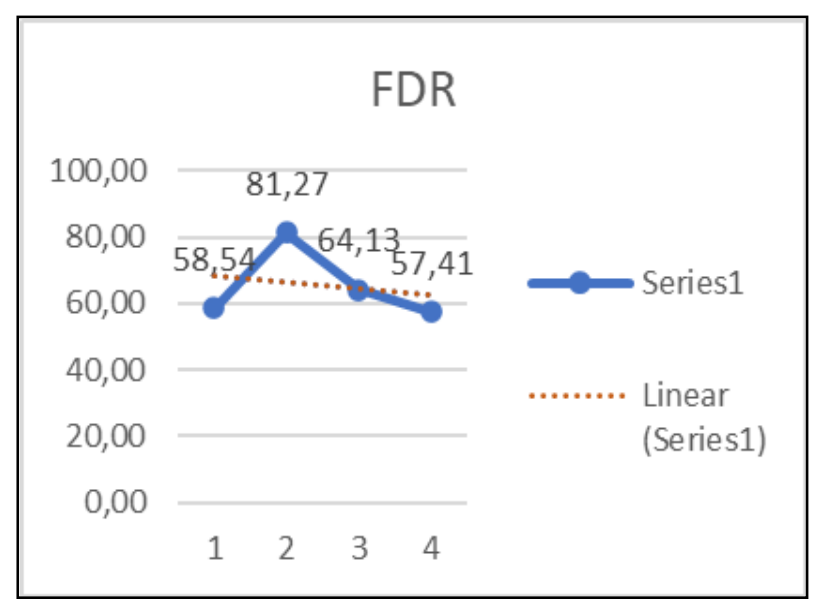

Figure 4. Trend analysis for FDR BTM Kaliwungu

Trend analysis for FDR can be seen in figure 4 which shows that before the covid-19 pandemic in 2017 (number 1), the graph was still below the standard in the utilization of third party funds, then in 2018 (number 2), the graph showed an increase, meaning there was an increase in liquidity, for 2019 (number 3) shows a declining graph. Meanwhile, during the Covid-19 pandemic, namely 2020 
(number 4) shows a graph that is getting lower than the previous year, it can be said that during the COVID-19 pandemic, there was a decrease in FDR.

\section{Conclusions}

Based on the processing of ratio calculations and trend analysis, it can be concluded that the Financial Performance of BTM Kaliwungu, seen from the CAR ratio, shows a healthy condition both before the covid-19 pandemic and during the covid-19 pandemic. Judging from the ROA ratio, it can be seen that before and during the Covid-19 pandemic, the results of the calculation of the criteria are quite good. For NPF during the Covit-19 period, the ratio was not good, meaning there was a delay in financing payments from customers to BTM Kaliwungu but not more than the standard. Likewise, the FDR from the ratio calculation shows that it is less than maximizing third-party funds both before and during the Covid-19 pandemic. In the future, it is hoped that BTM Kaliwungu can provide more financing to customers with proper financing analysis so that no delays or congestion will affect benefits or profits.

\section{Acknowledgments}

We are very grateful to the Accounting Department and the Institute for Research and Community Service, Universitas Muhammadiyah Semarang, for their support in publishing our research.

\section{REFERENCES}

[1] theconversation.com, "Bagaimana pandemi COVID-19 bisa memicu krisis perbankan di Indonesia," 2020. https://theconversation.com/bagaimana-pandemi-covid-19bisa-memicu-krisis-perbankan-di-indonesia-142559.

[2] BPS, "Ekonomi Indonesia Triwulan III 2020 Tumbuh 5,05 Persen (q-to-q) UNDUH BRS INI Jadwal Rilis : 2020-11-05," 2020-11-05, 2020. .

[3] KOMPAS, "Sri Mulyani Proyeksi Ekonomi Kuartal III Minus 2,9 Persen, Siap-siap Resesi,” 2019. KOMPAS.COM/MUTIA FAUZIA Artikel ini telah tayang di Kompas.com dengan judul \%22Sri Mulyani Proyeksi Ekonomi Kuartal III Minus 2,9 Persen, Siap-siap Resesi\%22, Klik untuk baca: https://money.kompas.com/r ead/2020/09/22/125539726/sri-mulyani-proyeksi-ekonomi

[4] G. Saab, "Micro financing and their 'Mission drift' orientation the MENA region case," Procedia Econ. Financ., vol. 30, pp. 790-796, 2015.

[5] BISNIS.COM, "ni 3 Risiko Perbankan Akibat Pandemi Covid-19 Artikel ini telah tayang di Bisnis.com dengan judul 'Ini 3 Risiko Perbankan Akibat Pandemi Covid-19', Klik selengkapnya di sini: https://finansial.bisnis.com/read /20200610/90/1250751/ini-3-risiko-perbankan-aki,” 2020. https://finansial.bisnis.com/read/20200610/90/1250751/ini -3-risiko-perbankan-akibat-pandemi-covid-19.

[6] A. R. Azhari and R. Wahyudi, "Analisis Kinerja Perbankan Syariah di Indonesia: Studi Masa Pandemi Covid-19," JESI (Jurnal Ekon. Syariah Indones., vol. 10, no. 2, pp. 96-102, 2020.

[7] R. Aniko, "Definisi dan Pengertian Baitul Tamwil Muhammadiyah." artikel: https://btm. school blog/2016/12/04/first-blog-post/(Diakses pada ..., 2016.

[8] R. Fadhillah, "Pengaruh Penerapan Good Corporate Governance Terhadap Kinerja Keuangan Dan Resiko Pembiayaan Di Bank Umum Syariah," in Prosiding Industrial Research Workshop and National Seminar, 2018, vol. 9, pp. 656-660.

[9] I. Fahmi, “Analisis kinerja keuangan,” 2012.

[10] S. E. Kasmir, Studi Kelayakan Bisnis: Edisi Revisi. Prenada Media, 2015.

[11] Riyanto Bambang, dasar-dasar pembelanjaan. 2010.

[12] R. C. Suwarno and A. M. Muthohar, "Analisis Pengaruh NPF, FDR, BOPO, CAR, dan GCG terhadap Kinerja Keuangan Bank Umum Syariah di Indonesia Periode 2013-2017," BISNIS J. Bisnis dan Manaj. Islam, vol. 6, no. 1, pp. 94-117, 2018.

[13] L. Dendawijaya, Manajemen Perbankan. Jakarta: PT Ghalia Indonesia, 2003.

[14] Niko Ramadhani, "Pengertian dan Cara Menghitung ROA (Return of Assets)," 2020. https://www.akseleran.co.id/blo g/rumus-roa/.

[15] A. Azmy, "Analisis pengaruh rasio kinerja keuangan terhadap profitabilitas bank pembiayaan rakyat syariah di indonesia," J. Akunt., vol. 22, no. 1, pp. 119-137, 2018.

[16] K. S. Dewi and P. Prasetiono, "Analisis Pengaruh ROA, NPM, DER, Dan Size Terhadap Praktik Perataan Laba (Studi Empiris Pada Perusahaan Manufaktur Yang Terdaftar Di Bursa Efek Indonesia Periode 2007-2010).” Fakultas Ekonomika dan Bisnis, 2012.

[17] I. Supriani and H. Sudarsono, "Analisis Pengaruh Variabel Mikro Dan Makro Terhadap NPF Perbankan Syariah di Indonesia," Equilib. J. Ekon. Syariah, vol. 6, no. 1, pp. 1-18, 2018.

[18] R. Amin, H. Rafsanjani, and A. Mujib, "Faktor-faktor yang Mempengaruhi Non-Performing Financing: Studi Kasus Pada Bank dan BPR Syariah di Indonesia," J. Masharif al-Syariah J. Ekon. dan Perbank. Syariah, vol. 2, no. 2, 2017.

[19] D. RASYIDIN, "Financing To Deposit Ratio (Fdr) sebagai salah satu penilaian kesehatan Bank Umum Syariah (Study Kasus Pada Bank BJB Syariah Cabang Serang)," Islam. J. Ekon. Islam, vol. 7, no. 1, 2016.

[20] M. Y. Wibisono and S. Wahyuni, "Pengaruh Car, Npf, Bopo, Fdr, Terhadap Roa Yang Dimediasi Oleh Nom," $J$. Bisnis dan Manaj. (Journal Bus. Manag., vol. 17, no. 1, pp. 41-62, 2017. 
[21] M. Sofyan, "Faktor-Faktor Yang Mempengaruhi Kinerja Keuangan BPR Syariah Di Indonesia," Sains Manaj., vol. 5, no. 2,2019 .

[22] M. K. Suhardjono, "Manajemen perbankan teori dan aplikasi," Penerbit BPFE. Jakarta, 2002.

[23] Peraturan Menteri Negara Koperasi Dan Usaha Kecil Dan Menengah Republik Indonesia Nomor 06/Per/M, "Peraturan Menteri Negara Koperasi Dan Usaha Kecil Dan Menengah Republik Indonesia Nomor 06/Per/M,” KUKM,
2006.

[24] D. Nurpitasari, "Pengaruh Pembiayaan Bagi Hasil Dan Pembiayaan Jual Beli Terhadap ROA Pada Bank Umum Syariah Melalui NPF Sebagai Variabel Intervening Periode 2012-2018.” IAIN PONOROGO, 2020.

[25] Bisnis.com, "Rasio Pembiayaan (FDR) Bank Syariah yang Ideal 98\%," 2014. https://finansial.bisnis.com/read/201403 14/232/210856/rasio-pembiayaan-fdr-bank-syariah-yang-i deal-98. 